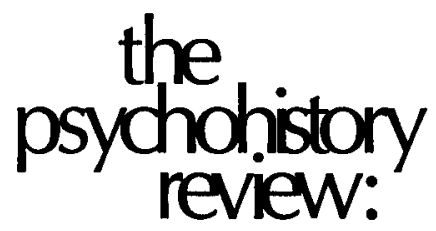

The Psychohistory Review's blend of history and psychology plays an increasingly important role in unfolding the past. Now in its nineteenth year of publication, the Review is an important periodical for psychologists, historians, psychoanalysts, sociologists, anthropologists and political scientists. When you finish your first issue you'll understand these comments:

"...the most important journal in the field of psychohistory; indispensable for both historians and clinicians..."

\title{
Bruce Mazlish
}

Massachusetts Institute of Technology

"In a field that is plagued with doubt and difficulty, The Psychohistory Review has set a consistently high standard of scholarship. More than any other single 'voice,' the Review talks in clear, sensible, and always interesting terms. It is, indeed, indispensable to further progress in psychohistorical studies."

\section{John Demos}

Department of History, Brandeis University

Psychohistory Review has been privileged to publish articles by respected thought-provoking writers. Recent articles include:

Thomas Fiddick, "The Repentant Revolutionary: Michael Bakunin and His Confession"

Ann Schofield, "To Do and To Be': Mary Dreier, Pauline Newman, and the Psychology of Feminist Activism"

Carol Z.Stearns and Peter N. Stearns, "Introducing the History of Emotion"

Charles B. Strozier, "Christian Fundamentalism, Nazism, and the Millennium"

Ronald R. Thomas, "The Narrative of Theory: The Novel in The Interpretation of Dreams"

The Psychohistory Review is a publication of Sangamon State University and the Group for the Use of Psychology in History, an affiliate organization of the American Historical Association.

The Psychohistory Review

Larry E. Shiner, Editor

Sangamon State University

Springfield, IL 62794-9243

217/786-6778 


\section{Scholars Workshop on the Rhetoric of Social History}

\section{Call for Fellows}

Scholars Workshop on the Rhetoric of Social History, at The University of lowa, Sunday, June 21 to Thursday, July 2, 1992. National Endowment for the Humanities Fellows from a variety of disciplines will contribute papers and participate in a twoweek workshop examining the ways through which social historians address, cultivate, engage, and seek to persuade their audiences. Paper proposals due March 1, 1991.

Codirectors are Jeffrey Cox, Shelton Stromquist, and Linda K. Kerber, the Department of History, The University of lowa. For a detailed description of the workshop, write to Project on Rhetoric of Inquiry, W700 Seashore Hall, The University of lowa, lowa City, IA 52242, or call 319-335-2753.

The Scholars Workshop is supported by The University of lowa, the Project on Rhetoric of Inquiry, and by a grant from the National Endowment for the Humanities, an independent federal agency.

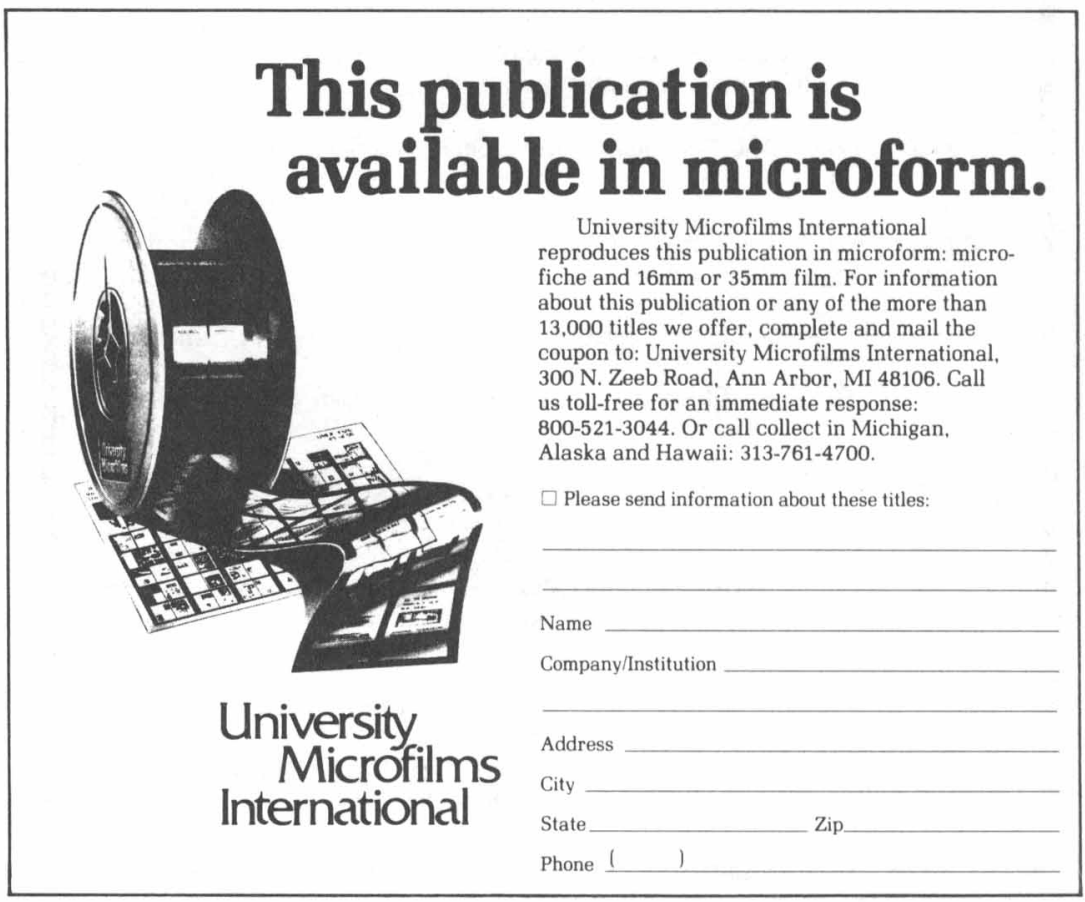




\section{THE REVIEW OF \\ BLACK \\ POLITICAL. \\ ECONOMY}

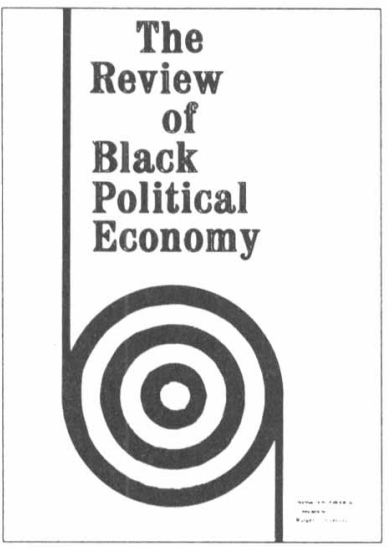

James Stewart, editor

Pennsylvania State University

Examines issues related to the economic status of black and Third World peoples. Identifies and analyzes policy prescriptions designed to reduce racial economic inequality.

\section{Recent articles include:}

Job Characterlstics and the Labor Force Participation Behavior of Black and White Male Youth

Donald R. Williams

The Changing Nature of Minority

Business: A Comparative Analysis of

Aslan, Nonminority, and Black-Owned

Businesses

Timothy Bates

A Measurement of Economic Growth for

Selected Caribbean Nations

Edward Nissan

Economic Forces, Structural

Discrimination and Black Family

Instability

Robert B. Hill

\section{Published Quarterly}

A publication of the National Economic Association, Clark Atlanta University.

Subscription rates:

Individuals: $\$ 25 / \mathrm{yr} ; \$ 45 / 2 y r s ; \$ 60 / 3 y r s$.

Institutions: $\$ 35 / y r$; $\$ 65 / 2 y r s ; \$ 90 / 3 y r s$.

Domestic first-class mail add $\$ 15 / y r$.

Foreign surface mail add $\$ 15 / y$.

Forelgn airmail add $\$ 30 / y$.

\section{TRANSACTION PERIODICALS CONSORTIUM}

Dept. 2000 Rutgers-The State University New Brunswick, NJ 08903 


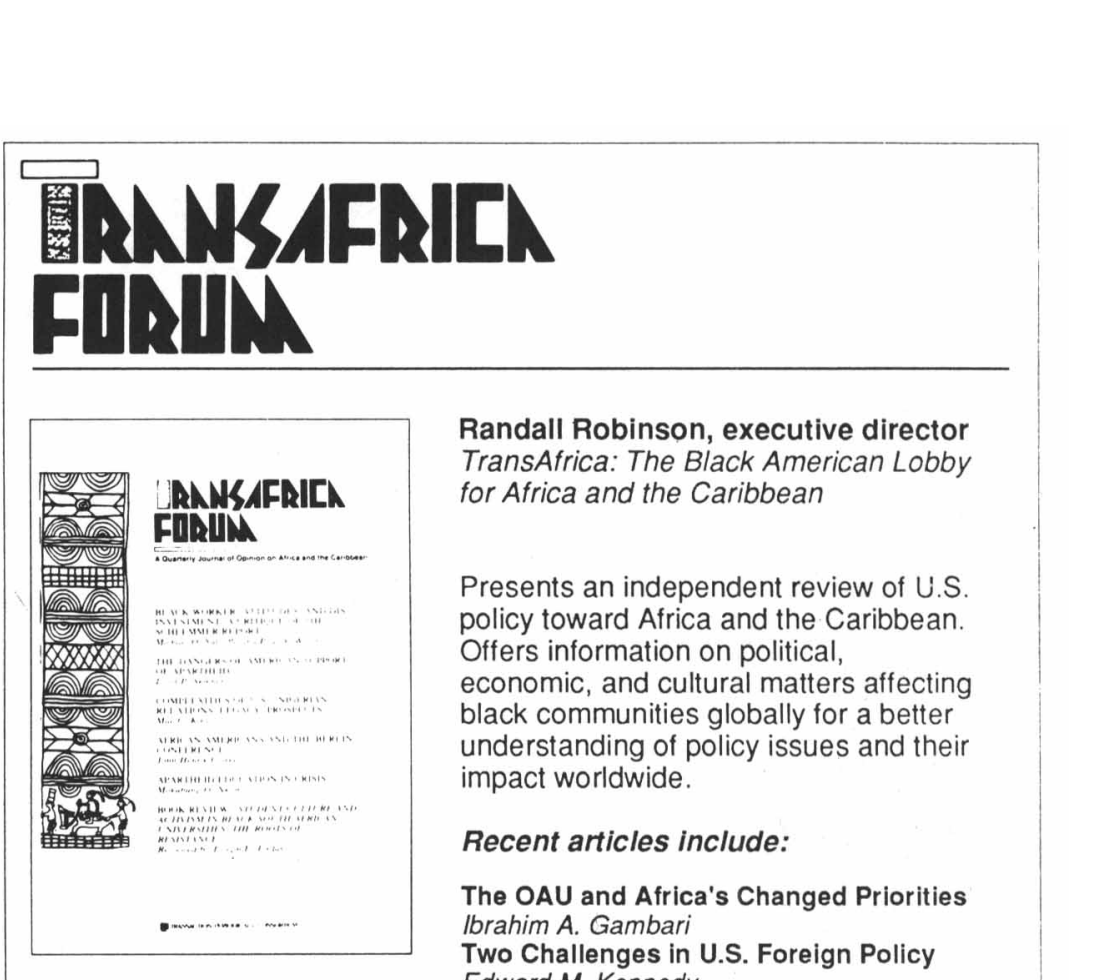

Two Challenges in U.S. Foreign Policy

Edward M. Kennedy

Nyerere and the Future of Tanzanian

Public Policy

Julius E. Nyang'oro

South Africa's Indaba: Solution or Sham? Michael O. Sutcliffe

\section{Published Quarterly \\ For Transafrica: The Black American Lobby for Africa and the Caribbean.}

Subscription rates:

Individuals: $\$ 20 / y r ; \$ 35 / 2 y r s ; \$ 50 / 3 y r s$. Institutions: $\$ 35 / y r ; \$ 65 / 2 y r s ; \$ 95 / 3 y r s$.

Domestic first-class mail add $\$ 10 / y r$.

Foreign surface mail add $\$ 15 / y$ r.

Foreign airmail add $\$ 30 / y r$. 
EDITOR

Eric Monkkonen, University of California, Los Angeles ASSOCIATE EDITOR

Robert P. Swierenga, Kent State University

BOARD OF EDITORS

Barbara Anderson, University of Michigan

William O. Aydelotte, University of Iowa

Lee Benson, University of Pennsylvania

Allan G. Bogue, University of Wisconsin

William Clagett, Florida State University

Ellen Dwyer, Indiana University

Heinz Eulau, Stanford University

Roderick Floud, University of London

David W. Galenson, University of Chicago

Alice Goldstein, Brown University

Myron P. Gutmann, University of Texas at Austin

David I. Kertzer, Bowdoin College

J. Morgan Kousser, California Institute of Technology

Robert C. Liebman, Portland State University

Terrence McDonald, University of Michigan

Patrick Manning, Northeastern University

Warren Miller, Arizona State University

Leslie Moch, University of Michigan, Flint

Karen Orren, University of California, Los Angeles

John Padgett, University of Chicago

Donald Parkerson, East Carolina University

Richard Steckel, Ohio State University

John J. TePaske, Duke University

Susan Cott Watkins, University of Pennsylvania

Ian Winchester, Ontario Institute for Studies in Education

SSHA EXECUTIVE DIRECTOR

Howard W. Allen, Southern Illinois University at Carbondale

EDITORIAL ASSISTANT

Matthew C. Lee 


\section{Cambridge University Press}

\section{The French Revolution}

An Economic Interpretation

\section{Florin Aftalion}

Martin Thom, Translator

A clear, accessible, and thoughtprovoking guide to the often ignored economic background to the French Revolution.

36241-5 Hardcover \$39.50

36810-3 Paper $\$ 12.95$

\section{The City as Text}

The Politics of Landscape

Interpretation in the

Kandyan Kingdom

Fames S. Duncan

A convincing demonstration of the influence that landscapes have over the ideas of political and religious life. 35305-X Hardcover $\$ 49.50$

\section{Class Formation and} Urban Industrial Society Bradford, 1750-1850

Theodore Koditschek

A study of Bradford, a small market town of 4,000 inhabitants in 1750 which exploded into a major industrial city of 100,000 by 1850 . The history of this town discloses with unusual force and clarity a process that was more gradually transforming the wider society of nineteenth-century Britain and subsequently spread throughout the world.

32771-7 Hardcover $\$ 69.50$
Making Algeria French Colonialism in Bône, 1870-1920 David Prochaska

A study, based on previously unavailable records, of French colonialism in Algeria, focusing on one particular colonial city, the city of Bône. Prochaska argues that, in making Bône a European city in the nineteenth and early twentieth centuries, the settlers effectively precluded any genuine rapprochement with the Algerians.

34303-8 Hardcover $\$ 39.50$

Community in

Historical Perspective Otto von Gierke, Antony Black, Editor Mary Fischer, Translator This is the first English translation of the first work of Otto von Gierke. The texts translated here have become essential reading for anyone interested not only in the history of ideas and alternatives to conventional socialism and liberalism, but also contemporary European affairs. 33487-X Hardcover \$49.50

\section{The Rise of}

Merchant Empires

Long Distance Trade in the Early Modern World, 1350-1750 Fames D. Tracy, Editor

The essays in this volume examine on a global basis the many different trading empires from the end of the middle ages to the eighteenth century. 38210-6 Hardcover \$44.50

At bookstores or from

\section{CAMBRIDGE UNIVERSITY PRESS}

40 West 20th Street, New York, NY 10011. Call toll-free 800-872-7423 outside NY State. 800-227-0247, NY State only. MasterCard/VISA accepted. Prices subject to change. 